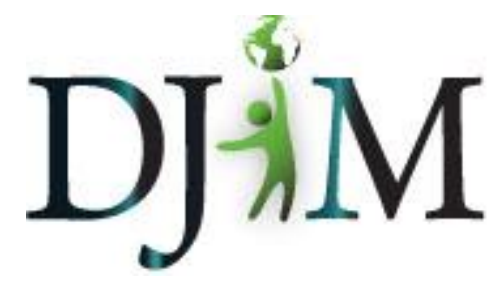

Volume7 - Spring 2011 djim.management.dal.ca

\title{
Subsidies and their Implications on Fisheries Management in St. Lucia
}

\section{Kaitlan Lay}

\begin{abstract}
Worldwide, fisheries subsidies contribute to fleet overcapacity, to overfishing, and to the decimation of the marine environment. Despite the fact that small-scale fisheries catch roughly the same amount of edible fish while causing less overall environmental damage, government preference for subsidy allotment continues to be in favour of industrial fisheries. St. Lucia is a Caribbean island which is recognized as a small vulnerable economy that relies heavily on its small-scale fisheries for economic and social development. The island nation has become largely dependent on foreign subsidies towards its fishery sector, with the majority of the subsidies designated to capacity enhancing programs, which lead to resource overexploitation. This report discusses the importance of directing subsidies away from programs that negatively impact the fishery and moving subsidies towards beneficial programs, with a focus on the development and implementation of effective fisheries management systems for St. Lucia.
\end{abstract}

\footnotetext{
About the Author(s): Kaitlan Lay is in her first year of the Master of Resource and Environmental Management program at Dalhousie. She has always been interested in environmental issues and has developed a strong interest in fisheries, fisheries subsidies and the ocean. This paper was written for the Fisheries Management (5021) class that Kaitlan took in her first semester of the MREM program.
} 


\subsection{Introduction}

Fisheries subsidies are financial transfers from public entities to the fishing sector, which help the sector make more profit than it would otherwise (Sumaila, et al., 2010). As stated by Markus (2010), "the exploitation of marine capture resources ultimately depends on the level of available fish stocks and a large share of subsidies fuel the race to fish by inducing investment incentives for the fisheries sector" (p. 1117). Fisheries subsidies are generally broken into three categories: (a) "beneficial", (b) "capacity-building", and (c) "ambiguous" (Sumaila et al., 2010). According to Sumaila et al. (2010), beneficial subsidies "enhance the growth of fish stocks through conservation, and the monitoring of catch rates through control and surveillance measures to achieve maximum long-term sustainable net benefits" (p. 3); while capacity-building subsidies "lead to disinvestments in natural capital assets such that the fishing capacity develops to a point where resource overexploitation makes it impossible to achieve maximum sustainable long-term benefits" (p. 4). Finally, ambiguous subsidies have impacts that are undetermined "i.e., they may lead to either investment or disinvestment in the fishery resource" (p.5).

Capacity-building government subsidies are the driving force behind large-scale fisheries, which contribute to fleet overcapacity, overfishing, and negative environmental impacts. According to Khan et al. (2006), "such subsidies result in fishery resources being overexploited, as they contribute directly or indirectly to the build-up of excessive fishing capacity, thereby undermining the sustainability of marine living resources and the livelihoods that depend on them" (p. 5). Of the estimated \$25 -29 billion in annual subsidies given to fisheries worldwide (Sumaila et al., 2010), the majority goes to industrial fisheries, while smallscale fisheries are at a disadvantage due to their typical remoteness, lack of infrastructure, and marginal political power. (Pauly,2006). There are various types of small-scale fisheries in existence around the world making them difficult to define; however, Salas, Chuenpagdee, Seijo, and Charles (2007) compiled a list of common characteristics of small-scale fisheries to assist with the differentiation from industrial fisheries:

(a) targeting of a mix of species using multiple types of boats and fishing gears, making it difficult to evaluate the state of the resources and the fishing intensity exerted; (b) low levels of capital investment by fishers, and the use of labourintensive harvesting, processing and distribution methods to exploit the fishery resources; (c) a wide range of landing sites used by fishers along the coast (often in small communities), making it difficult to effectively record catches and fishing effort; (d) seasonal use of fishing resources, and fishing income that is often complemented by other economic activities (with the frequent presence of part-time fishers in the fishery); (e) significant provision through fishing as protein and jobs for people in coastal areas; (f) attraction of migrant people to the coast in the search for income, with typically less investment needed to enter the fishery, in terms of capital and skills, or the option of becoming "workers" in private companies; (g) limited 
power of fishers to influence the fish market, given their small-scale capital commitment; and consequently a greater dependence on middlemen for marketing and loans; (h) lack of social mechanisms for health and employment provision to the fishers. (p. 2)

Such fisheries, in comparison to industrial fisheries, generally use less energy-intensive fishing gear, discard little to no fish, target different fish species based on their availability, employ 25 times more people, and use one-quarter the fuel to catch roughly the same amount of edible fish (Jaquet \& Pauly, 2008). The reconstruction of fisheries subsidy policy programs is necessary for the survival of our oceans and must take into account the small-scale and artisanal fisheries that exist worldwide. Some small and vulnerable economies (SVE) rely heavily on fishing and would suffer greatly if forced to comply with the same subsidy policies as industrial fisheries (Stephen \& Murray, 2008). Various beneficial subsidies are important in assisting the development of sustainable management and governance, which is why some SVE fisheries have requested for special and differential treatment (International Centre for Trade and Sustainable Development [ICTSD], 2007).

The Caribbean State of St. Lucia is recognized as a small vulnerable state, ranking 19 on the World Bank's Relative Vulnerability List (Stephen \& Murray., 2008), and relies heavily on its small-scale fisheries for food security, employment, rural development, and tourism (Haughton, 2003). The majority of fish caught per year is consumed locally, with fish consumption increasing due to a growing tourism sector and the adoption of healthier lifestyles by the local population (Food and Agriculture Organization of the United Nations [FAO], 2010). In St. Lucia the fishing industry is considered an important vehicle for providing income and sustenance to rural coastal communities as unemployment is still a major issue in the country (FAO, 2010). Fish landings occur at 17 coastal communities, with Vieux Fort and Gros Islet catching 44\% of the total annual landings (FAO, 2000).

St. Lucia would benefit from the implementation of beneficial subsidies to develop and improve management of its coastal and marine space, and the elimination of capacity-building subsidies, such as fuel subsidies, which are directly related to overfishing and could lead to the collapse of fish stocks. This article will address current fisheries management in St. Lucia and how subsidies are applied to the management system. It will then assess the decline of foreign subsidies and its effects on fisheries management. Finally, it will discuss subsidies and their influence on the development of various management systems and their application to fisheries management in St. Lucia. 


\subsection{Fisheries management and subsidies in St. Lucia}

St. Lucia is a small Caribbean nation that relies heavily on its marine resources for social and economic development. As stated by Haughton (2003), the fishery contributes "towards food security, poverty alleviation, employment, foreign exchange earnings, development and stability of rural and coastal communities, and culture, recreation and tourism" (p.1). According to the FAO 2010 country profile for St. Lucia, the fisheries sector employs 2,319 registered fishermen and approximately 120 fish vendors and processors and has a gross output value of US\$ 7.4 million (FAO, 2010). Between 1990 and 2000 the number of fishing vessels more than doubled (FAO, 2000), the fleet is now made up of approximately 690 vessels, mainly consisting of fiberglass pirogues and some wooden canoes, both of which are powered by outboard motors in the range of 40-115 horsepower (FAO, 2010). The main fisheries include: offshore migratory pelagics, which comprise approximately $65 \%$ of the annual landings, shallow shelf and reef species, as well as queen conch, sea turtles, and sea urchins (FAO, 2010).

\subsection{Current management of St. Lucian fisheries}

The development and management of St. Lucian fisheries is based on two important pieces of legislation: the Fisheries Act, No. 10 of 1984, and the Fisheries Regulations SI No. 9 of 1994. As stated by FAO (2010) "these two instruments relate to fisheries access agreements, local and foreign fishing licensing, fish processing establishments, fisheries research, prohibited fishing gears and methods, marine reserves and fishing priority areas, fisheries enforcement, and specific restrictions for certain utilized resources". The Department of Fisheries, the Marine Police Unit and the district police of the Royal Saint Lucia Police are responsible for the enforcement of fisheries legislation (FAO, 2010). The mission statement in the Plan for Fisheries Management of St. Lucia (2001) reads as follows: "The Government of St Lucia is committed to the conservation and sustainable use of fisheries resources for the long-term benefit of the people of St Lucia" (p.7). As noted in the FAO Country Profile (2010), specific fisheries management objectives for St. Lucia are to:

- maintain or restore populations of marine species;

- preserve rare or fragile ecosystems and habitats;

- protect and restore endangered marine and freshwater species;

- promote the use of selective fishing gear and practices and prevent the use of destructive gear and methods;

- factor traditional knowledge and interests of coastal communities and artisanal fisheries into fisheries management;

- ensure effective monitoring and enforcement of fishing and other marine resource uses; 
- promote relevant scientific research;

- ensure integrated planning and a collaborative approach in terms of policies for the sector, fisheries and coastal zone management; and

- cooperate with other nations in the management of shared, straddling and highly migratory stocks.

\subsection{Fisheries subsidies in St. Lucia}

Many of the objectives stated in the management plan for the fisheries of St. Lucia would not be able to be met without the financial assistance (subsidies) provided from foreign counties, (also known as Overseas Development Assistance (ODA), such as Japan, Canada, and members of the European Union. According to Alder, Fox and Jorge (2006):

Overseas development assistance can be described as aid given by developed countries to support economic development in developing countries. This form of aid has been practiced by many countries with strong economies for decades and is distinct from humanitarian aid which focused on short-term aid to relieve human suffering caused by a crisis such as war or natural disasters. ODA has been a significant component of the world economy since the 1960's, and in some countries a significant source of revenue. (p. 54)

As stated by Alder et al. (2006), "the impetus for donor countries to assist recipient counties in developing their economies through resource extraction sectors including fisheries ranges from altruism to economic or strategic (military) advantage" (p. 54). An example of such funding is the management program that was funded by the Government of Canada to assist St. Lucia with an extensive regional fisheries assessment and management program (FAO, 2010). However, it should be stated that a large amount of the foreign subsidies that are given to St. Lucia are used to provide advanced gear and vessels, which are considered capacityenhancing subsidies (Sumaila et al., 2010). St. Lucia has also invested subsidy monies into fisheries infrastructure (processing, cold storage, and marketing) and granted over EC\$ 3.5 million in loans over six years, which has allowed fishers to invest in their own boats instead of working as crew (FAO, 2010). According to Sumaila et al. (2010) St. Lucia's total subsidy estimate for 2003 was US $\$ 4,038,000$, with $\$ 2,726,000$ falling under the capacity-enhancing subsidies.

The continued funding towards the fishery sector has encouraged people from SVEs to participate in small-scale fisheries for employment, although it has been noted that despite the economic contribution of the fishers to their national economies their livelihood has not been significantly improved. The disconnect between fishery participation and personal economic gain is linked to the fact that as fish stocks decline fishing efforts increase, with fishers 
spending more money and time to catch the same or reduced amount of fish (Salas et al., 2007).

\subsection{The decline of foreign subsidies and its effects on fisheries management}

St. Lucia, being a SVE relying mainly on small-scale fisheries, is heavily dependent on fisheries subsidies for developmental purposes. Government subsidies and ODA have allowed the country to further develop the fisheries sector, which has helped stabilize the nation's economy. However, many of these subsidies are considered capacity-enhancing and have contributed to overfishing. There has recently been a significant decline in ODA to the fisheries sector. "Donor fatigue" is preventing countries, such as St. Lucia, from addressing the issue of overfishing and establishing management and enforcement infrastructures (Alder et al., 2006). Management, which is considered a beneficial subsidy because it attempts to regulate exploitation and to make the fishery sustainable, saw funding increase until the 1990s when it peaked in 2000, and has since been in decline. Management funding usually goes towards training and expansion within government agencies, establishing monitoring and enforcement programs, and in some countries reducing capacity (Alder et al., 2006). Therefore, the decline of ODA funding is a major concern, especially for developing countries like St. Lucia who are facing management issues. Lack of funding may prevent any possibility of improving fisheries management of overexploited fish stocks such as the queen conch and lobster in St. Lucia (Caribbean Regional Fisheries Mechanism [CRFM], 2009; FAO, 2010).

A second issue that presents itself in regards to Caribbean subsidies is that the subsidies are generally not reported quantitatively and the information is usually only found in grey literature (Khan et al., 2006). To ensure the proper allocation of fishery subsidies and to alleviate the pressure on fish stocks due to capacity-building subsidies, it is necessary to collect up to date data regarding estimates of stock status.

\subsection{Subsidies and the development of management systems}

The elimination of capacity-building and ambiguous subsidies without addressing effective fisheries management systems can lead to a lack of coherence in fisheries policy as a whole; therefore, both must be evaluated together (Haughton, 2003; Markus, 2010). Although ODA funding towards fisheries management has been in steady decline over the years (Alder et al., 2007), with an estimated US $\$ 700$ million out of US $\$ 13$ billion allocated to fisheries management programs and services (Khan et al., 2006), it is still necessary for countries to assess their current management plans and look towards future improvement and development. Without goal planning, the state of SVE fisheries will continue to decline. In order to ensure the proper management of the fisheries and allocation of subsidies it is necessary to 
look at management and subsidies together. Long-term management plans need to be set in place with the management process being more participatory and transparent. The lack of success of past and current management practices used in the Caribbean are due to a lack of surveillance, weak institutions, unclear legal management instruments, and limited involvement of fishers in the management process (Salas et al., 2007). As stated by Salas et al. (2007) "fishery managers should utilize a set of multiple, mutually reinforcing management tools, to increase the robustness of the system and the resilience of the fishery overall" (p. 12). Some useful tools and frameworks could include: the precautionary approach, ecosystem-based approach, co-management, adaptive management, marine protected areas, and livelihood and economic diversification.

\subsection{Precautionary approach}

The precautionary approach is a management method used to deal with uncertainty and allows managers to err on the side of caution (Milley \& Charles, personal communication, September 30, 2010). It can also provide the foresight to avoid unacceptable or undesirable situations (Charles, 2007). As stated by Garcia (1994) the precautionary approach "inverses the course of action, requiring that measures are taken first and subsequently relaxed if research demonstrates convincingly that they aren't necessary" (p.5). Applying the precautionary approach to St. Lucian fisheries would help managers and fishers reach operational and measurable targets, as well as base management objectives on biological and socio-economic considerations and increase involvement of stakeholders (FAO, 2010).

\subsection{Ecosystem-based approach}

The ecosystem-based approach takes a broader view of the species in the environment by trying to maintain productivity, preserve biodiversity, and protect habitat (Fisheries Resource Conservation Council [FRCC], 2007). This approach takes into account the four components of sustainability: ecological, economic, social, and institutional (FRCC, 2007). As stated by the FAO (2003), "An ecosystem approach to fisheries strives to balance diverse societal objectives, by taking into account the knowledge and uncertainties about biotic, abiotic and human components of ecosystems and their interactions and applying an integrated approach to fisheries within ecologically meaningful boundaries"(n.p.) The complex marine ecosystems of St. Lucia include mangrove forests, seagrass beds and reefs. These ecosystems are under threat from marine-based activities such as dredging and indiscriminate anchoring of boats, as well as land-based activities, which increase the sediment levels in coastal waters (Plan for Managing the Fisheries of Saint Lucia, 2001). The application of an ecosystem-based approach to St. Lucian fisheries could assist in deciphering the connections between the various aspects of the ecosystem and the areas of highest stress. 


\subsection{Adaptive management}

Adaptive management, as stated by the FAO (2008), is a management approach "that explicitly recognizes the occurrence and potential consequences of uncertainties resulting from incomplete knowledge and adopts strategies and methods aimed explicitly at 'learning by management', progressively reducing uncertainties and risk" (p. 73). Adaptive management allows for improvement of expectation-generating tools by adjusting action (P. Duinker, personal communication, December 7, 2010). Adaptive management could be a useful tool for St. Lucian fisheries in regards to the shared resources of migratory pelagics. Because shared resources are affected by the fishing efforts of other countries, it is important to integrate new information with existing data on a regular basis. Adaptive management allows managers and fishers to account for uncertainty by properly using the available information (Charles, 2007).

\subsection{Co-management}

Co-management is a partnership between community and government that deals with social, conservation, and rationalization issues. Co-management recognizes the validity of traditional and local management systems as well as the government's authority. One of the most important aspects of this approach is the increased resource stewardship and management that is achieved through the involvement of those most affected: the fishers. Co-management results in a decentralization of power by offering fishers the means to take part in the decision making process (Milley \& Charles, personal communication, October 13, 2010). The institution of co-management arrangements with fishers can help maintain population levels that can sustain long term optimum yields for social and economic purposes (Mohammed, Parker \& Willoughby, 2003). According to the FAO (2008) active participation of stakeholders "helps in empowering the actors, mobilizing people, building-up consensus, improving the knowledge base, and identifying expectations and perceptions"(p. 30). Through the use of communitybased co-management, appropriate use rights and management rights can be acknowledged and assumed locally to improve local knowledge, accept management rule, resolve conflicts, and have positive effects on fishery conservation and sustainability (Milley \& Charles, personal communication, October 13, 2010). Co-management of coastal-marine areas has increased in St. Lucia and is seen by the local fishers as an important means of resolving constraints of coastal fishing (FAO, 2010). There are currently a number of co-management arrangements that exist in St. Lucia: the Soufriere Marine Management Area (SMAA), the sea urchin fishery, as well as a sustainable harvesting of a mangrove resource (FAO, 2010). The continued and future use of co-management would be advantageous because it has produced positive outcomes for past management situations for the island. 


\subsection{Marine Protected Areas (MPAs)}

MPAs are selected areas of ocean that have been set aside to assist in the repopulation of fish and other marine species and to protect sensitive habitats as well as spawning and rearing grounds (Living Oceans Society, 2010). The implementation of MPAs allows for rehabilitations of specific fishing grounds and offers the opportunity for managers and fishers to witness any changes that occur within and around the protected ocean area. Recently, there have been great efforts in St. Lucia to manage the near-shore fisheries, with a number of MPA reserves being established in the SMAA. Some studies have shown that there has been a tripling of fish biomass in the marine reserve areas, while fishermen have reported significant increases in catch from adjacent areas. In the end the management authority from these MPA reserves have become self financing through diving and yacht anchoring fees (Reefbase, 2001).

\subsection{Livelihood and economic diversification}

Livelihood and economic diversification is an important aspect that should be considered in terms of St. Lucia's fisheries. Multispecies fishing, maximizing benefits, multiple sources of income, and diversifying the economy are all areas that can help alleviate pressure on current fish stocks. Diversifying livelihoods in St. Lucia would help to deter current urban residents from moving to coastal communities to fish, which increases pressure on the fishery, creates issues with use rights, and causes tension between fishers. Providing alternate employment options, such as freshwater shrimp, tilapia, or seaweed aquaculture, will help maintain the existing coastal community and the management practices that have been set in place by that community and will boost the country's economy. Aquaculture development has been an important focus of the St. Lucian government. According to the FAO 2010 country profile St. Lucia currently has 17 acres of freshwater shrimp and tilapia ponds in operation and it is estimated that the island has the capacity to support a total of 50 acres of ponds. There are currently 40 people employed through aquaculture, therefore, if the full 50 acres become operational, shrimp, tilapia and seaweed could provide employment for a considerable amount of St. Lucians (FAO, 2010).

\subsection{Discussion and conclusions}

Future subsidy money granted to St. Lucia should first be used to assess the current situation of fish stocks to provide up to date information, which can be used to develop and implement necessary management tools. Each fishery must be evaluated individually, yet not in isolation from the larger system. Subsequently an appropriate management program must be developed made up of a number of tools working together. Once the management plan has been instated it is important to address the issue of enforcement, as the United Nations Environmental Programme (UNEP) (2007) states "good management depends in significant 
part on effective enforcement" (p. 24). The proper management of resources will allow for current and future generations of fishers to benefit from healthy fish stocks, which will provide a secure socio-economic environment and allow St. Lucian fishers to have access to stable livelihoods and contribute to the country's economy.

Subsidies are a critical factor in the progression of management, research and development, and MPA for developing nations. Without ODA many SVE fisheries would not be what they are today. For small developing countries like St. Lucia it is crucial to place importance on the beneficial subsidies rather than the capacity-building subsidies that contribute to excessive fishing capacity. The majority of current subsidies to St. Lucia fall under the capacity-building section, which goes towards fuel subsidies, boat construction, renewal and modernization programs, foreign access agreements, etc. (Sumaila et al., 2010). This continued build up of overexploitation undermines the sustainability of marine living resources and the St. Lucia livelihoods that depend on them (Khan et al., 2006). It is understood that capacity-building subsidies are favored over beneficial subsidies as they allow for more fish to be caught "now"; however, it must be brought to attention that if there is a continued use of capacity-building subsidies the number of fish to catch "now" will continue to diminish until there is nothing left. To avoid the possibility of an empty ocean, it is necessary to use subsidies to develop and implement effective management plans that will allow for the proper development and management of marine space for small nations like St. Lucia. 


\section{References}

Alder, J., Fox, H. \& Jorge, M. (2006). Overseas development assistance to fisheries as a subsidy. . In U. Sumaila \& D. Pauly (Eds.), Catching more bait: a bottom-up reestimation of global fisheries subsidies (Fisheries Centre Research Reports, 14.6). Retrieved from University of British Columbia Fisheries Centre website http://fisheries.ubc.ca/publications/reports/report14 6.php

Caribbean Regional Fisheries Mechanism (CRFM). (2009). CRFM fishery report 2009. Volume 1. Report of fifth annual scientific meeting. Retrieved from http://www.caricomfisheries.com/PublicationsandDocuments/CRFMFisheryReports/t abid/85/Default.aspx

Charles, A. (2007). Sustainability and resilience in natural resource systems: Policy direction \& management institutions. Retrieved from husky1.stmarys.ca/ charles/PDFS_2005/018.pdf

Cunningham, S., Dunn, M. R. \& Whitmarsh, D. (1985). Fisheries economics: An introduction. London: Mansell Pub.

Fisheries Resource Conservation Council (FRCC). (2007). Sustainability framework for Atlantic lobster 2007. Retrieved from http://www.frcc.ca/2007/Strategic\%20Lobster\%20Framework\%202007.pdf

Food and Agriculture Organization of the United Nations (FAO). (2000). Information on fisheries management in St. Lucia. Retrieved from http://www.fao.org/fi/oldsite/FCP/en/LCA/body.htm

Food and Agriculture Organization of the United Nations (FAO). (2003). The ecosystem approach to fisheries management. Retrieved from http://www.fao.org/fishery/topic/13261/en

Food and Agriculture Organization of the United Nations (FAO). (2010). Fisheries and aquaculture country profiles St. Lucia. Retrieved from http://www.fao.org/fishery/countrysector/FI-CP LC/en

Garcia, M. (1994). The precautionary principle: Its implications in capture fisheries management. Ocean \& Coastal Management, 22, 99-125.

Garcia, S. \& Food and Agriculture Organization of the United Nations. (2008). Towards 
integrated assessment and advice in small-scale fisheries: Principles and processes. Retrieved from ftp://ftp.fao.org/docrep/fao/011/i0326e/i0326e.pdf

Government of St. Lucia. (2001). Plan for managing the fisheries of St. Lucia. Retrieved from www.slumaffe.org/fmp.pdf

Haughton, M. (2003). Fisheries subsidy and the role of regional fisheries management organizations: The Caribbean experience. Retrieved from http://www.unep.ch/etu/Fisheries\%20Meeting/submittedPapers/MiltonHaughton.pdf

International Centre for Trade and Sustainable Development (ICTSD). (2007). Special and differential treatment for small and vulnerable countries based on the situational approach. Retrieved from ictsd.org/.../special-and-differential-treatment-for-smalland-vulnerable-countries-based-on-the-situational-approach.pdf

Jaquet, J. \& Pauly, D. (2008). Funding priorities: Big barriers to small-scale fisheries. Conservation Biology, 22, 832-835.

Khan, A., Sumaila, U., Watson, R., Munro, G. \& Pauly, D. (2006). The nature and magnitude of global non-fuel fisheries subsidies. In U. Sumaila \& D. Pauly (Eds.), Catching more bait: a bottom-up re-estimation of global fisheries subsidies (Fisheries Centre Research Reports, 14.6). Retrieved from University of British Columbia Fisheries Centre website http://fisheries.ubc.ca/publications/reports/report14 6.php

Living Oceans Society. (2010). Marine Protected Areas. Retrieved from http://www.livingoceans.org/programs/mpa/

Markus, T. (2010). Towards sustainable fisheries subsidies: Entering a new round of reform under the common fisheries policy. Marine Policy, 34(6), 1117-1124.

Mohammed, E., Parker, C. \& Willoughby, S. (2003). Barbados: Reconstructed fisheries catches and fishing effort, 1940-2000. Retrieved from www.seaaroundus.org/report/ CAtrends/4-Mohammed-PartkerWilloughby.pdf

Reefbase. (2001). Resources overview - St. Lucia. Retrieved from http://www.reefbase.org/global database/default.aspx?section=r1\&region=0\&countr $\mathrm{y}=\mathrm{LCA}$ 
Salas, S., Chuenpagdee, R., Seijo, J. \& Charles, A. (2007). Challenges in the assessment and management of small-scale fisheries in Latin America and the Caribbean. Retrieved from linkinghub.elsevier.com/retrieve/pii/S0165783607001555

Schrank, W. (2003). Introducing fisheries subsidies. FAO Fisheries Technical Paper - T437. Retrieved from ftp://ftp.fao.org/docrep/fao/006/y4647e/Y4647e00.pdf

Sharp, R. \& Sumila, R. (2009). Quantification of U.S. Marine Fisheries Subsidies. North American Journal of Fisheries Management, 29, 18-32.

Soufriere Marine Management Area (SMMA). (2005). The creation of the Soufriere marine management area. Retrieved from http://www.smma.org.lc/index.html

Stephen, A. \& Murray, P. (2008). International trade and fisheries: Implications for fisheries management and development of small vulnerable Caribbean states. Retrieved from http://www.scribd.com/doc/ 8406 368/International-Trade-and-Fisheries-in-SmallVulnerable-Caribbean-States

Sumaila, U., Pauly, D. \& University of British Columbia. (2006). Catching More Bait: A BottomUp Re-Estimation of Global Fisheries Subsidies ( $2^{\text {nd }}$ Version, 2007). Fisheries Centre Research Reports, 14(6). Vancouver, B.C: Fisheries Centre, University of British Columbia.

Sumaila, U., Khan, A, Dyck, A., Watson, R., Munro, G., Tydemers, P. \& Pauly, D. (2010). A bottom-up re-estimation of global fisheries subsidies. Retrieved from http://www.springerlink.com/content/518668r862l271u7/

United Nations Environmental Programme (UNEP). (2007). Sustainability criteria for fisheries subsidies. Retrieved from www.unep.ch/.../fishierSubsidiesEnvironment/ UNEPWWF_FinalRevi09102007.pdf 